\title{
GLOBALIZATION AND ISLAMIC EDUCATIONAL CHALLENGES: Views from East Javanese Pesantren
}

\author{
Akhmad Nurul Kawakip \\ Universitas Islam Negeri (UIN) Maulana Malik Ibrahim, Malang \\ Email: akhmad.nurul@pai.uin-malang.ac.id
}

\begin{abstract}
There have been social, political and religious changes in Indonesia since the fall of the New Order regime in 1998. Globalization has furthered acceleration of the change. These forces have given tremenduous impacts on Indonesian educational system, and Islamic educational system (pesantren) in particular. This article examines how pesantrens respond globalization and explores what pesantrens have developed during the era. Based on an ethnographic study in pesantrens in East Java, this study explores the conception, policy and practices of Islamic education in the pesantren in this globalization era. It argues that globalization increases the complexity and the necessity of learning and teaching development, particularly in preparing students (santri) to deal with the challenges of rapid growth and change of contemporary world. The responses of pesantren on global challenges have been shown through the development of its traditional system, namely curricula development and leadership. The new pesantren educational system, management and leadership are now sustainable and relevant to the modern world. The shifting educational paradigm in the pesantren's policy supports Sadalah's and Hefner's contention that the Islamic educational system in the contemporary era needs to adopt, accept and integrate the teaching content of non-traditional Islamic subjects into their programs.
\end{abstract}

Keywords: Pesantren, globalization, shifting educational paradigm

DOI: https://doi.org/10.20414/ujis.v24i1.385

\section{Introduction}

THE FALL of Indonesian President Soeharto in 1998 opened a political opportunity for civil groups, including Islamic educational institution, to express their political, social and 
educational ideal more openly within the public arena. The dynamics of policy on educational system seems to be continued in the subsequent times during the administration of Susilo Bambang Yudhoyo presidency up to the present, in the second term of President Joko Widodo. ${ }^{1}$ In other words, after the falling of president Soeharto, Indonesian society has been experiencing many changes. The changes are not only in terms of political life but also in the economic, social, cultural, educational spheres. The traditional Islamic boarding schools in Indonesia, which are called as "Pondok Pesantren" or "Pesantren", are no exception. Globalisation is believed to have affected the traditional life of Indonesian pesantrens. ${ }^{2}$

This is an ethnographic study of Islamic educational institutions and applies qualitative approach. The data were collected through in-depth interviews and observations and gathered relevant archives and documents as secondary sources. It focuses on three pesantrens in East Java and compares and contrasts the strategies of each pesantren in response to the current needs and demands of modernization and globalization. The three pesantren, namely Nurul Jadid, Sidogiri and al-Hikam, chosen for this study have a reputation of transformation into a new model of Islamic educational institution. ${ }^{3}$ For this purpose, through an ethnographic method, this study explores the conception and practices of these pesantren communities concerning cultural and

${ }^{1}$ In the first time, during Indonesia history, the Indonesian government policy toward pesantren educational system can be identified on the legal framework for the pesantren educational system. This is mainly reflected in law number 20/2003 on educational system (Undang-Undang Sistem Pendidikan Nasional), article 4 (30). In 2007, through the government regulation number 55 of 2007, Madrasah diniyah have been integrated into Indonesian educational system. The policy continued. In 2019, the government enacted The Law of Pesantren (Undang-undang Pesantren) No. 18/2019.

2 Tan Charlene, "Educative Tradition and Islamic School in Indonesia," Journal of Arabic and Islamic Studies 14 (2014): 47-62.

${ }^{3}$ These pesantrens have had reputation as a center of religious education. For instance, Pesantren Sidogiri is the oldest pesantren in East Java that has established in 1745 or before the emergence of Indonesia as a nation state. While, Pesantren Nurul Jadid is represent of a khalaf (modern) pesantren, the educational program are quite varied. Pesantren al-Hikam represent urban-university based based pesantren, located in Malang. 
educational transformation. Margarate Le Compte and Jean Schensul point out that ethnography is an approach to learning about social and cultural life of communities, institutions, and other settings. ${ }^{4}$ This article answered two main questions: How have the pesantrens responded to globalization and how have such responses influenced their institutional policy on Islamic education?

Rukhsana Zia argued that the notion of globalization is clearly not a monolithic concept. ${ }^{5}$ This article highlights one dimension of globalization that relates to education. In other word, the term 'globalisation' gives more emphasis on educational perspective in this present study. Wood cited in Ronald Luken-Bull argues that education is widely recognized as an important part of how a society engages modernization and globalization. ${ }^{6}$ Martin Carnoy and Diana Rhoten identifies that globalization, in educational dimension, is the quality of national educational system, which is increasingly competitive internationally and that information technology play important role in the educational system in this globalized world. ${ }^{7}$

\section{The concept of globalization}

Globalisation is an extremely wide concept which may manifest in an infinitive variety of ways. It is argued, globalization has many facets and hence many possible challenges. In other words, the notion of globalization is clearly not a 'monolithic' concept. ${ }^{8}$ Robertson defines globalization as a concept that refers

\footnotetext{
${ }^{4}$ Margarate Diane Le Compte and Jean J Schensul, Designing and Conducting Ethnography Research (Walnut Creek: Altamara Press, 1999), 1.

${ }^{5}$ Rukhsana Zia, ed., Globalization, Modernization and Education in Muslim Countries (London: Sience Publisher, 2006), 4.

${ }^{6}$ Ronald A. Lukens-Bull, "Two Sides of the Same Coin: Modernity and Tradition in Islamic Education Indonesia," Journal Anthropology \& Education Quarterly 32, no. 3 (2001): 350-372.

7 Martin Carnoy and Diana Rhoten, "What Does Globalization Mean for Educational Change? A Comparative Approach," Comparative Education Review 46 , no. 1, special issue on the meanings of globalization for educational change (2002): 5 .

${ }^{8}$ Zia, Globalization, 4.
} 
to the compression of the world as a whole. ${ }^{9}$ Meanwhile, according to Anthony Giddens globalization is really about the transformation of time and space action in distance. ${ }^{10}$ Arjun Appadurai points out that the significance of globalization is mass migration and electric media and the use of the later to create "diasporic public spheres" across the boundaries of nation-states. ${ }^{11}$

John Wiseman has shown that globalization of culture has also given rise to heightened localized resistance and the remixing of cultural flows and identities, often referred to as 'hybridization'. ${ }^{12}$ Meanwhile, Sadaalah, as cited in Holger Daun and Geofrey Walford, points out that Islamic educational orientation in the globalization age tends to translate western values into Islamic framework. ${ }^{13}$ David Birch have proposed that globalization poses a threat, in Asia and elsewhere, both to the sovereignty of the nation state, and the viability of some local cultures. ${ }^{14}$

With respect to this argument, some pesantrens in East Java have responded to globalization and modernization by seeking the most viable way to maintain their cultural values. Many pesantren leaders argue that globalization is a threat to their institution and values. ${ }^{15}$ One of the objectives of my article is to examine these propositions. In this sense, in addressing a changing world, some pesantren create an educational system closely in line with the Indonesian government system; however, others try to keep their original form and create a 'limited adoption' of some aspects,

${ }^{9}$ Roland Robertson, Globalization: Social Theory and Global Culture (London: Sage, 1992).

10 Anthony Giddens, Beyond Left and Right: The Future of Radical Politics (Cambridge: Polity Press, 1994).

${ }^{11}$ Arjun Appadurai, Modernity at Large: Cultural Dimension of Globalization (Minneapolis: University of Minneapolis Press, 1996).

12 John Wiseman, Global Nation? Australia and the Politics of Globalisation (Cambridge: Cambridge University Press, 1998).

${ }^{13}$ Holger Daun and Geofrey Walford, Educational Strategies among Muslim in the Context of Globalisation: Some National Case Studies (Netherlands: Brill NV, 2004), 48-49; Holger Daun, Educational Restructruring in the Context of Globalization and National Policy (New York: Routledge Falmer, 2002).

14 David Birch, Asia: Cultural Politics in the Global Age (Australia: Allen \& Unwin, 2001), 70.

${ }^{15}$ Ronald A. Lukens-Bull, Two Sides of the Same Coin: Modernity and Tradition in Islamic Education Indonesia, 350-372. 
considered to be required in the global era. This phenomenon illustrates several difficulties that arise in discussing the problem of transition from the traditional to modern style. Despite the differences in how globalization is currently understood, I would like to emphasize the dimension of globalization in educational and cultural dimension. The term educational dimension refers to changes taking place in the educational programs, educational goals and orientations offered in the East Javanese pesantrens. Cultural transformation refers to the changes in leadership authority and the pesantrens' tradition.

\section{Educational dimension}

Daun and Walford identify that the impact of globalization process has affected school management. ${ }^{16}$ Schools are now concerned not only with preparing children for adult roles, but also responding to the needs of national and local economic and moral requirements. Furthermore, school face a dilemma in handling a series of contradictory needs, demands and requirements such as religious needs versus secularism, national versus international, and mother tongue versus international language. In line with this perspective, Currie et al. points out that the government requires schools to serve national interests within the global marketplace. ${ }^{17}$ Meanwhile, Muluk et al. argue that generic skills, which are, consist of information communication and technology (ICT), leadership, religious competencies, entrepreneurship and communication skills are need to be taught in the globalization era. ${ }^{18}$

The changing political circumstances throughout the country's history have also had impact on the development of the pesantren educational system, particularly their educational programs. Hefner et.al. argues that Islamic education in contemporary

${ }^{16}$ Daun and Walford, Educational Strategies, 16-17.

17 Jan Currie and Janise Newson, Universities and Globalisation (Critical Perspectives) (London: SAGE Publications, 1998), 12.

18 Safrul Muluk et al., "Developing Generic Skills at an Islamic Higher Education Institution Curriculum in Aceh, Indonesia," Higher Education, Skills and Work-Based Learning 9, no. 3 (January 1, 2019): 445, accessed May 8, 2020, https://doi.org/10.1108/HESWBL-06-2018-0064. 
Indonesia has become more, not less, involved with the general education and "western" style subjects and pedagogies. ${ }^{19}$ From this point of view, the Indonesian pesantren is different from madrasa (Islamic school) in Pakistan. Talbani contends that "in the postcolonial era, the traditionalist continued to believe that Western secular education promotes immorality and anti-Islamic or sometimes Christian ideas and continued to oppose and modify it" $^{\prime 2}{ }^{20}$

\section{Cultural dimension}

According to Birch, globalization refers to a particularly cultural dimension, and from this point of view; electronic technology is seen to be able to disseminate cultural texts- films, television, newspaper, magazines- across national borders. ${ }^{21}$ In line with this perspective, John L. Esposito in his book the Islamic Threat points out:

"Religious leaders, who were initially resistant, have come to depend upon modern technology. Village Muslims no longer live in relatively isolated worlds solely dependent upon their local religious leaders for knowledge of Islam. Television, radio and audiocassettes now expose them to a diversity of voices (preachers) and messages of interpretations of Islam". ${ }^{22}$

In this point of view, many students in pesantren communities face new opportunities as a result of modernization, such as an increase in internet access, technological, and communicative advances. All these facilities, of course, have not been encountered before within traditional life in the pesantren. Whatever the reasons, cultural dynamics which for so many years have existed in the pesantren community, are now being questioned, and one of the important aspects of these changing dynamics is the rolechanging of the traditional pesantren in Indonesian educational system. From this point of view, pesantren have no choice but to

${ }^{19}$ Hefner, Robert W et al, Schooling Islam: The culture and politics of modern Muslim education (New Jersey, Princeton University Press, 2007), 34-35.

20 Aziz Talbani, "Pedagogy, Power, and Discourse: Transformation of Islamic Education," Comporative Education Review 4, no. 1 (1996): 66-82.

${ }^{21}$ Birch, Asia: Cultural Politics in the Global Age.

${ }^{22}$ John L. Esposito, The Islamic Threat: Myth or Reality (New York: Oxford University Press, 1992), 10. 
deal with the challenges of time. In other words, pesantren as religious and educational institutions, currently face the dilemma between preserving the traditional identity of pesantren as the center of Islamic teachings and allowing them to modernize, which means to accept secular educational teachings.

In the context of the pesantrens' perspective, globalization is simply associated with modernization and westernization. Ustādh $\mathrm{N}$ (an Islamic teacher at Pesantren al-Hikam) states that globalization has had negative impact on Indonesia since the wave of modernization and globalization has reduced the country's traditional values within the new educational system. He talks about the impact of globalization as the following:

"Indonesia once had established values, as can be seen in the successful establishment of the Republic of Indonesia. These values were the values of 1945. However in the 1980s, these values became lost and now completely lost. The problem is that these days, young people want to be like the United States or Japan as quickly as possible. But, they often forget that Japan has held on to its values tenaciously"23.

In regards to the responses of the Muslim community in dealing with the process of globalization, Monshipouri and Matomani cited in Zia, identify that there are three paradigms of Muslim groups in response to globalization: conservatives, globalizers and reformers. ${ }^{24}$ The first paradigm (i.e. conservative's paradigm) considers Islamic teachings as immutable and tends to implement an Islamic state. A Muslim group with such a view sees globalization as tied to Western politics, ideological, commercial interests and a new form of cultural imperialism. In short, they regard globalization as Western hegemony in today's world. Meanwhile, the second paradigm (i.e. globalizer's paradigm) is at the other end of the spectrum and insists on a paradigm shift in Islam calling on it to adapt the international standards of human rights among other things. And the last paradigm is the reformer's paradigm. The reformer's paradigm is between the two extremes and view revivalism as an integral Islamic tradition. This group implements modern concepts like democracy and human rights

${ }^{23}$ Lukens-Bull, Two Sides, 32

${ }^{24}$ Zia, Globalization, 6. 
within the Islamic framework. A Muslim group with such a view sees Islamic concepts such as ijtihād (independent reasoning), shūrā (consultation), ijmā' (consensus of the 'ulamā/religious scholars) and bay $\bar{a}$ (holding leaders to certain standards of accountability) as consonant with universal and global norms and standards of living in today's world.

As a social institution, the East Javanese pesantrens have their own characteristic that are considered quite different from other Indonesian educational institutions, particularly in the process of transformation and the educational management. Unlike public schools, for instance, the pesantren educational form is a reflection of the kiai's approaches to the study of Islam as the founder and central figure. Abdullah S. Zarkasyi points out that traditionally a kiai manages all activities in the pesantren including material, economic, physical aspects and the like. ${ }^{25}$ In this sense, Clifford Geertz was not sure about the ability of kiai to be cultural brokers between Indonesia and modernity. ${ }^{26}$ Meanwhile, in such contemporary school communities, educational leaders are faced with external and internal challenges and expectations. According to Duignan:

"Leaders cannot do it all by themselves. They have to work with and through others to achieve their organization's vision and goals. There is simply not enough time in the workday for one person to provide the scope and depth of leadership required in the contemporary school communities". ${ }^{27}$

The adoption and efforts of pesantren to deal with the needs of society is part of the cultural and educational transformation of pesantren. For this purpose, it seems to give certain directions in the use of the social constructionist perspective for the understanding of the phenomena in East Javanese pesantren. The basic assumption of the social constructionist perspective is that

25 Abdullah Syukri Zarkasyi, "Langkah Pengembangan Pesantren," in Religiusitas Iptek, ed. M. Anies (Yogyakarta: Pustaka Pelajar, 1998).

${ }^{26}$ Clifford Geertz, "The Javanese Kijaji: The Changing Role of a Cultural Broker," Comparative studies in Society and History 2, no. 2 (1960): 228-249; Clifford Geertz, The Religion of Java (Chicago: University of Chicago Press, 1976).

27 P. Duignan, Educational Leadership: Key Challenges and Ethical Tension (Cambridge: University Press, 2006), 22. 
knowledge is never free from interests, politics or human experiences. It is something created based on individuals' perspective, simultaneously constructed with ideological, political and cultural interests. ${ }^{28}$ In this sense, an education system is not something taken for granted; it is constructed by certain people to be taught to others.

\section{Globalization from the eyes of Pesantren Community}

As the discussion in the concept of globalization shows, the main impact of globalization raises key issues about educational systems in educational institutions. Thus, the processes of globalization have produced reconsiderations of the aims of education, contents of education, processes or methods by which those are delivered, and ways in which the outcomes are assessed. In other words, seen from an educational point of view, globalization is a challenge faced by many contemporary educational institutions.

In the case of this paper, in the context of pesantren, globalization is quite varied. According to Ustādh D, a senior Pesantren Sidogiri ustädh:

"Globalisation is a process that cannot be avoided. Its influence is spread through the channels of information and communication. For the pesantren globalization is a challenge, because globalization influences not only the economy but also culture and education. In this respect, pesantren should be ready to be compete globally, not only compete in Indonesia but also possibly compete with Islamic education from the Middle-East and also with western education and Europe. As the pesantren have their own particular cultural and intellectual traditions and system of belief, globalisation poses a threat that cannot be defeated without adopting educational values from outside the pesantren. This is a great challenge for pesantren". ${ }^{29}$

From this point of view, Ustādh D states a positive impact of globalization and modernization, saying that "the point is simply that educated people tend to accept the scientific view of the world". Therefore, pesantren should be able to take part in

28 Thomas Schwandt A., "Three Epistemological Stances for Qualitative Inquiry: Interpretivism, Hermeneutics and Social Constructivism," in The Handbook of Qualitative Research, ed. Norman K. Denzin and Yvonna S. Lincoln, 2nd ed. (London: SAGE, 2000), 189-213.

${ }^{29}$ Interview with Ustādh D, Sidogiri, January 22, 2019. 
'colouring' the bombardment of mass information and telecommunication. This is one of the reasons why Pesantren Sidogiri has created a website (www.sidogiri.com). He suggests that by creating a website, Pesantren Sidogogiri may be able to promote Islamic teachings based on pesantren tradition. In this regard he said: "we spread information through the pesantrens' website based on our tradition". Furthermore, Ustādh D sees globalization as a means of faciliting better ways of communication between people from pesantren and people from the wider spectrum. They would be able to share patterns of thought and behaviour including those areas concerned with religion and theology. In terms of the academic context, in which pesantren operates, pesantren should be free to access all kinds of materials. Seen from this perspective, the discourse about educational values at Pesantren Sidogiri provides many resources, not only limited to materials written by affirmed scholars of the medieval period, but also modern and controversial authors such as Nasr Hamid Abu Zayd, and Mohammed Arkoun. ${ }^{30}$ Although generally, Pesantren Sidogiri disagrees with liberal thought, it seems that Pesantren Sidogiri tries to train their students to become accustomed to different schools of thought (madhhab). It is hoped then, in terms of intellectual discources, that students will exercise proper attitude such as progressive, inclusive and tolerant toward different perspectives in Islam.

In terms of educational competitivenes, Ustādh D points out that pesantren should be able to compete with other educational institutions. Therefore, even though Pesantren Sidogiri tends to maintain the old tradition, in order to meet the society needs, Ustādh D argues that Pesantren Sidogiri should be able to provide life skills and vocational education for students, that do not

\footnotetext{
${ }^{30}$ Nasr Hāmid Abū Zayd, an Egyptian author, wrote an academic book that many Islamic scholars accused of being offensive to Islam (an apostate/murtad). In this case, Abu Zayd had used hermeneutic to interpret the Al-Qur'ān. As an impact, according to the Egyptian courts, he had to divorce his wife. Since he can no longer live in Egypt, he and his wife left for Holland in 1996. While, Mohammed Arkoun, an author who wrote numerous books in Arabic, English and French, the most influential book is Rethinking Islam, he argues that religious dimension should be included in socio-historical analysis.
} 
disturb the old tradition. For this reason, in recent times the teachings at Pesantren Sidogiri not only focus on religious teachings but also vocational skills and training for economic development. However, it is important to note that even though Pesantren Sidogiri has adopted secular knowledge, such as English language, computer skills and job skills training or vocational skills, at the same time the pesantren maintained the value of religious teachings supervised by ustādh (teacher) as well as kiai (senior teacher).

Based in the author's fieldwork and interview, in terms of the nature of leadership in the educational management, the model of leadership has become more dispersed rather than concentrated in the central figure of one kiai. This is due to the implementation of educational program. In response to this, Pesantren Sidogiri has tried to change its organizational approach. Therefore, the pesantren community involved in the educational management.

Meanwhile, in regards to globalization issues according to Ustādh NC, a senior ustādh at Pesantren al-Hikam, globalization is seen as a threat to cultural identity. He states:

"Globalization contributes to the weakening of cultural identity because the globalization process itself has become a vehicle to mediate some of the Western ways of life in our societies. I refer here to three interrelated valuestrends namely individualism, consumerism, and secularism. Therefore, it is obligatory for pesantren to equip students' characters with moral values as well as mastery in secular disciplines, which they obtain from their universities". 31

It seems, for Ustādh $\mathrm{NC}$, the concept of globalization is understood as cultural matters that are easily spread to different societies, and as a result additional social values challenges the existence of traditional values. However, it seems his perspective is with the stress on western values rather than other countries. ${ }^{32}$

${ }^{31}$ Interview with Ustādh NC, Malang, January 9, 2019.

32 Based on NC's opinion the threat of Western values in Indonesia has been occurring particularly in urban areas, mostly in Java such as Jakarta, Surabaya and Malang. The pride of using local traditional dresses, food and the like seem to be replaced by branded materials and food for the purpose of following the lifestyle trend which is extremely influenced by hedonism. All these phenomena, Ustādh NC sees as a threat to traditional culture. Interview with Ustādh NC, Malang, January 9, 2019. 
This might occur because Pesantren al-Hikam is located in Malang city, where the growing of mall facilities or shopping centers grows rapidly. Nowadays, in Malang city it is easy to find shopping centers with transnational corporations such as McDonalds and KFC, seen as symbols of cultural influence, which are becoming popular with students. The current controversial issue is about the project of developing a shopping center called MATOS (Malang Town Square). MATOS is situated near universities and schools. Many people protest this project, since they think that the development will destroy the educational environment. They believe that the educational environment should be far away from the shopping centers. As there will be many facilities provided at MATOS, many worry that it will attract students to go to MATOS rather than going to their schools.

From the above data, it is argued that the people of pesantren are concerned about cultural dimensions of globalization and the pesantren community believes that globalization is not only threatening but also a challenge and an opportunity to appropriately respond to the issue by preparing the students with skills and knowledge needed in present society. From this perspective, the pesantren community cannot choose not to take part in the globalization process. Some pesantren data shows that the community can eliminate or reduce some negative impacts of globalization. For instance, it is believed that globalization promotes industrialization and capitalization. In this perspective, the leader of pesantren argues that pesantren should be able to train students to compete for positions in the industrial sectors. In this sense, it seems that pesantren is aware that with increasing industrialization and the growth of professional diversification structures, 'an exclusively pure religious training' will not be sufficient to prepare students for future challenges. Consequently, new fields of knowledge are becoming relevant for students in the pesantren community. Meanwhile, in principle, at Pesantren Sidogiri the students are not prepared to be employed in such professions, since the emphasis of teaching is based more on character building. However, Pesantren Sidogiri has no choice but to accommodate the needs of society; therefore the pesantren made 
the effort to format a new specialization for students, as argued by Ustādh M:

"Pesantren Sidogiri developed a curriculum based on the senior santris' interests. In doing so, the curricula committee opened three specialized programs. The objective of this curriculum development was to accommodate the santris' interests, rather than to prepare the students for employment in a specific sector of the economy, as santri should be able to undertake any sort of work. It is possible for the students who have specialized in education to become successful as a $m u^{\prime}$ 'amalah (self-employed man) and vice verse, since this has already happened". ${ }^{33}$

At the same time, Pesantren Sidogiri's alumni association encourages their members to become self-employed or not dependent on the Indonesian government employment. In general, they usually work in private sectors, such as teaching at their villages or in madrasah particularly affiliated with Pesantren Sidogiri or even establishing and managing a new pondok pesantren or madrasah. ${ }^{34}$

It is argued that pesantren try to create a 'hybrid culture'; this is because they appreciate and are open to other cultures. In other words, globalization is seen as an opportunity to create new generations to answer the needs of society. Wiseman has shown that the globalization of culture has also given rise to heightened localized resistance and the remixing of cultural flows and identities often referred to as 'hybridization'. ${ }^{35}$ Seen from this perspective, pesantren communities have their own strategies employed to deal with social change. Meanwhile, Julie Stephen

${ }^{33}$ Interview with Ustādh M, January 23, 2019.

${ }^{34}$ One of the distinguishing characteristics of Pesantren Sidogiri, compared to other pesantren, is the effort to build a network. In this point of view, one of Pesantren Sidogiri's missions is to build Madrasah filial (or branch of school). The idea came into existence in 1963 and year-by-year this program showed significant progress, and as result, at present three have been 103 schools or pesantren, which are affiliated with Pesantren Sidogiri. In terms of curricula and teacher's resources, Pesantren Sidogiri also supports the branches of the school. Therefore, the students who have already finished their studies will be employed as teachers at various branches of the school. Nearly 600 students every year at Pesantren Sidogiri are sent to teach at other schools outside Pesantren Sidogiri. Interview with Abdurrahman, Sidogiri, February 12, 2019.

${ }^{35}$ Wiseman, Global Nation. 
points out that 'the growth of cultural pluralism and ideas of hybridization where increased cultural contacts have produced new hybrid identities'. ${ }^{36}$

\section{The relationship of the Pesantren and the Indonesian Government:}

The changing political circumstances, to some degree, have had a significant impact on the educational reform on Indonesian pesantren, particularly with regards to the pesantren's accreditation. In the past, it was common to see the Indonesian government paying little attention to pesantren development. As indicated by Lukens-Bull, “during 1994-1995, government favoritism was perceived toward Muhamadiyah and led some pesantren people to feel some distance from Suharto's regime". ${ }^{37}$ From his point of view, Muslih Usa indicates that "it is strange based on the fact that most of the Indonesian population is Muslim; however the Indonesian government pays little attention to Islamic education". 38

However, the fall of Indonesian president Soeharto in 1998 opened a political opportunity for civil society groups, including the pesantren community to express their political, social and educational ideals more openly. This study indicates that in the reformation era, pesantren were increasingly more open to intervention from the Indonesian government. This might be due to the fact that some pesantren leaders felt more involved in the political process, even though they also had parliamentary representatives.

The Indonesian government has already made an effort to develop the quality of the pesantren educational system. For instance, the Government provides a small subsidy and also acknowledges pesantren certificates. In this sense, the relationship between the pesantren communities and the State has shown a 2007).

${ }^{36}$ Julie Stephen, Approach to Globalisation (Melbourne: Victoria University,

${ }^{37}$ Ronald A. Lukens-Bull, Peaceful Jihad (London: Palgrave Macmillan, 2005), 85.

${ }^{38}$ Muslih Usa, Pendidikan Islam di Indonesia antara Cita dan Fakta (Yogyakarta: Tiara Wacana, 1991), 11. 
cooperative approach. Nevertheless, this is not to negate from the fact that there is still some kiai within the pesantren community who might not fully accept the policies of Indonesian government toward pesantren. Overall, pesantren are open to Indonesian government intervention particularly in order to develop nonreligious subjects that aim to prepare santri for the future challenges and to develop the quality of the pesantren educational system.

The pesantren communities agree to accept any help, programs or support as long as the funding does not have any underlying message or there is no consequence in terms of moral dependence. In this sense, Pesantren Salaf (traditional pesantren) has even received financial support from the Indonesian government. These institutions will not change their educational system by implementing the state curriculum. In response to this situation, Pesantren Salaf has only compromised in terms of adopting secular subjects in a limited scope, as long as the adoption doesn't change the main references of teaching and learning, i.e. kitab kuning of Pesantren Salaf.

As stated previously, from an historical point of view, in the colonialism era, the pesantren kept its distance from the Dutch. This was because pesantren applied a non-cooperative approach to deal with governance at that time. Meanwhile, during the New Order regime, only those pesantren that had already implemented the government educational system received Indonesian government accreditation. However, in the reform era, some Pesantren Salaf, which still maintained the original pesantren educational programs (i.e. without introducing the Government curricula), also received accreditation from the Indonesian government.

\section{a) Legal framework for the Pesantren Educational system}

The current trend in the reform era, which started in 2003, showed significant attention from the Indonesian government to the existence of pesantren as educational institutions. This is particularly supported through Law No. 20/2003 on National Educational System (Undang-Undang Sistem Pendidikan Nasional), article 4 (30). The Law effectively identifies Pondok Pesantren as a 
subsystem of the national educational system. The Law states, religious educational models can be formed as diniyah, pesantren, pasraman, pabhaja samanera and the like.

In 2006, the signing by the Minister of Religious Affairs (SK Mentri Agama) recognized the degrees granted by some traditional pesantren. This policy makes them equivalent to those received by students who graduated from Indonesian state-owned schools. Therefore, santri can continue their degrees in Indonesian universities. As a result, after the program was launched by the Ministry of Religious Affairs, the pesantren graduates, particularly at the senior level, were able to continue their academic degrees, not only in state Islamic colleges such as IAIN, UIN or STAIN, but in general universities as well. ${ }^{39}$

The effort to integrate the pesantren educational system into the national educational system also continued and accelerated in 2007 with the Government Regulation (Peraturan Pemerintah). The Government, in the reform era, issued Regulation No.55 of 2007 for the pesantren educational system. With this Regulation, the Indonesian pesantren educational system has been integrated into the Indonesian national educational system. As a consequence, the Indonesian government must pay attention to the pesantren's educational development, particularly by providing a small subsidy to some pesantren..$^{40}$ From this point of view, according to Ustādh M the Deputy of Pesantren Sidogiri, the Pesantren decided to accept the Indonesian government subsidies:

"Related to BOS bantuan operasional sekolah (or the school operational funds) which is provided by the Indonesian government, Pesantren Sidogiri does not have the right to refuse the Government financial support. Since the purpose of these funds is for santri affairs, the Pesantren decided to accept the donation; since the BOS is not allocated for the Pesantren as an institution" ${ }^{41}$

39 Muhammad Maftuh Basyuni, Revitalisasi Spirit Pesantren: Kiprah, dan Refleksi (Jakarta: Departemen Agama Republik Indonesia, 2007).

${ }^{40}$ One of notable Indonesian Government subsidies is through BOS or the school operational funds budget. The Indonesian government provided Rp. 235.000 per year for a student at the primary level. While for a student at the senior level, the Government provided Rp. 324.500 (approximately US\$25).

${ }^{41}$ Interview with Ustādh M, January 23, 2019. 
The quote above indicates a new approach, the openness to deal with external donations i.e. from the Indonesian government. This is considered as a new approach, since in the past the pesantren totally refused any kind of financial support from the Indonesian government.

In terms of accreditation, the Indonesian government also recognised the pesantren's degrees. Therefore, Indonesian government has already accepted some of Pesantren Salaf's certificates. ${ }^{42}$ It was common knowledge that during the New Order regime the Indonesian government did not recognize certificates from pesantren, particularly from Pesantren Salaf, today in the reform era, Pesantren Salaf's educational system has already been integrated into the Indonesian government educational system. Therefore, the Indonesian government has accepted some certificates from Pesantren Salaf.

Furthermore, based on the Regulation above, the Indonesian government through the Ministry of Religious Affairs has also provided the opportunity for Pesantren Salaf to run a 9-year compulsory education in the primary level. ${ }^{43}$ This policy makes the pesantren educational system equal to that of the national system run by public schools, with the requirement to add some 'secular' subjects such as mathematics, Bahasa Indonesia, and natural sciences. It is easy for some pesantren to accept the State policy, since the Regulation does not interfere with the pesantrens' traditional study of the Kitab Kuning and the development of the pesantren's educational values. The Indonesian government policies, once again, bring significant implications, since the existence of Pesantren Salaf remains with its original identity. In others words, the Regulation and the Law of the national educational system, for some pesantren, can be implemented without destroying the integrity of Pesantren Salaf.

42 The data from the Ministry of Religious Affairs indicates that currently there are 32 pondok pesantren salaf throughout Indonesia that have already accepted the Indonesian government accreditation. See, Laporan Subdit V tahun 2018, unpublished report.

${ }^{43}$ In Indonesia, Pendidikan Dasar or elementary educational level is called nine-year compulsory education. It is hoped that children under 18 years old will be able to pursue at least nine years of schooling. 
The government Regulation will also contribute to the program of compulsory education launched by the Indonesian government in 1994 in becoming a reality. In Indonesia, according to the law, children should attend primary school for nine years, but in reality poverty was mostly to blame for this not actually occurring. ${ }^{44}$ Seen from this perspective, pesantren also share the responsibility to bring compulsory education successfully into Indonesia. In other words, pesantren becomes the alternative educational model, which is affordable for the village children and adolescents.

\section{b). Study support for santri to study at Indonesian State Universities}

The other important effort, on a practical level, which aims to develop Indonesian pesantren as an Educational system, is being pursued particularly through the Ministry of Religious Affairs (MORA). For this purpose, the MORA has already established an institution, called Directorate of Diniyah and Pesantren Education. In this point of view, it is argued that the Indonesian government (i.e. through the Directorate of Diniyah Education and Pesantren) takes into account the future of pesantren's santri, particularly those who study at Pesantren Salaf, since many of them could not pursue further degrees in Indonesian government schools. In the past, it was regrettable that some potential santri at Pesantren Salaf could not participate in a wider spectrum of Indonesian development since their certificates were not recognized by the New Order regime. Therefore, in the reform era the Indonesian government, i.e. MORA, has already implemented programs that aim to improve the quality of the pesantren educational system. ${ }^{45}$

Based the MORA data, the Indonesian government has already provided scholarships for pesantren students since 2005 in order to pursue degrees in various Indonesian state universities. For this purpose, MORA already signed MoU's (memorandum of understanding) with both Islamic state universities (such as the

\footnotetext{
${ }^{44}$ In the 1945 Constitution of Indonesia, article 31, section 1, states: "each and every citizen shall have the fundamental right to education".

${ }^{45}$ Amin Haedari, Transformasi Pesantren (Jakarta: Lekdis \& Media Nusantara, n.d.), 50 .
} 
Faculty of Medical Doctors of UIN Syarif Hidayatullah Jakarta and UIN Sunan Ampel Surabaya) and some Indonesian state universities such as Bandung Technological Institute (ITB), Bogor Agricultural Institute (IPB) and Airlangga University (UNAIR), Surabaya. The first program was launched in 2005, and at that time, there were already 13 santri who were studying at the Faculty of Medicine at UIN Jakarta as well as 50 santri (students) who were studying at Bogor Institute for Agricultural Studies (IPB).

The phenomenon of santri who have opportunities to pursue degrees in various Indonesian universities is similar to what is called 'santri kelana' (a knowledge -seeking wanderer), moving from one pesantren to another pesantren. According to Dhofier one of the important aspects of the culturally intellectual pesantren educational system, in the early part of the establishment of pesantren, was the emphasis on the journey of its students. ${ }^{46}$ In this sense, Dhofier identified a typical wandering santri was a santri who was traveling from one pesantren to another pesantren. ${ }^{47}$ The aim was to seek knowledge from the best authorities on various specialist Islamic branches of knowledge. Such was the tradition of the wandering santri in the nineteenth and twentieth centuries. Currently, in the era of reformation, the wandering santri travels from pesantren to various Indonesian universities.

I also argue that this tradition has positive values for future wandering santri's and could make way for pesantren to refute common images given by some people that pesantren are isolated institutions. This is because it was common knowledge in the past to see pesantren curricula emphasizing pacification and memorization rather than a curriculum for transformation. ${ }^{48}$ Furthermore, the pesantren environment was seen as isolated from the developments of sciences and modern society. Those who were in the circle of the Pondok Pesantren were not able to solve

${ }^{46}$ Zamakhsyari Dhofier, Tradisi Pesantren (Jakarta: LP3ES, 1982).

${ }^{47}$ Ibid.

${ }^{48}$ Muhammad Fuad, “Islam, Modernity and Muhammadiyah's Educational Programme," Journal Intern-Asia Cultural Studies 5, no. 3 (2004): 401-414. 
problems that arose due to modern development. ${ }^{49}$ The role of doctors, lawyers, engineers, educators and economists needed by the community could not be produced by a traditional Islamic educational institution but by a modern one. ${ }^{50}$ Thus, the Pondok Pesantren seemed not to adequately serve the national plans for modernization. All these assumptions might have been true in the past however, since pesantren students now have the same opportunities as students in public schools, this assumption is not to appropriate any more. This phenomenon would have been seen as something unimaginable in the past.

Meanwhile, with regards to the government's efforts to reform the pesantren educational system, the responses from the pesantren people are quite varied. According to Ustādh D from Pesantren Sidogiri, the pesantren's independence faced a challenge. On one hand, the Indonesian government regulation would lead to recognition of pesantren accreditation; on the other hand, there was some concern that the government policy would lead to diminution of pesantren independence.

"I think that effort of the government for the pesantren educational system has a double edged sword. On the one hand, it may pose a fear of loss of the uniqueness of the characteristics of pesantren as an independent educational institution. On the other hand, it may meet the needs of society eager for government policy - acknowledging Pesantren salaf's certificates". ${ }^{1}$

Meanwhile, Kiai M, a young kiai from Pesantren Nurul Jadid, is quite optimistic about the future of pesantren in dealing with the efforts of the Indonesian government. For him Pesantren Nurul Jadid is now able to accelerate the educational system toward a modern educational system. The efforts of the Indonesian government are also seen as an attempt to adjust the rapid changes in the needs of society and new social circumstances.

49 Taufiq Abdullah, "The Pesantren in Historical Perspective," in Islam and Society in Southeast Asia, ed. Taufiq Abdullah and S. Siddique (Singapore: Institute of Southeast Asian Studies, 1996), 80-107; Geertz, "The Javanese Kijaji."

${ }^{50}$ Ahmad Jainuri, "The Reformation of Muslim Education: A Study of the Aligarh and the Muhamadiyah Educational System," Journal IAIN Sunan Ampel 15 (1999): 202-28.

${ }^{51}$ Interview with Ustādh D, Sidogiri, January 22, 2019. 
"We do not fear the loss of the original identity of pesantren, because of the state's efforts to develop pesantren. Even though we have developed our educational system at Pesantren Nurul Jadid, Madrasah, toward the international standard, we know that our system is based on our Prophet's teaching: "teach your children with something that you have not learnt before, since your children are not created the same as the time in which you were born". 52

With regards to the support of Pesantren Sidogiri's development and financial autonomy, the Pesantren had a reputation for refusing any donations support or subsidies from outside organisations such as from the Indonesian government as well as international development agencies. In 2006, for instance, an Australia agency under the LAPIS program (Learning assistance program for Islamic schools) tried to offer donations, however Pesantren Sidogiri refused to accept this donation. Meanwhile, Pesantren Nurul Jadid has already accepted support from international development agencies and also has partnership program with other agency. There are already programs which aim to improve the quality of the educational system in Pesantren Nurul Jadid, such as teachers' workshops for English teachers in cooperation with IALF Bali and IALF Surabaya, AVI Australia, and the like.

There is general understanding or general perception in Indonesia context that such an approach at Pesantren Sidogiri is considered conservative or an old-fashioned approach. Seen from a political context, Nurcholis Madjid states that the policy of some pesantren trying to distance themselves from the Indonesian government are regarded as the manifesting a non-cooperative attitude. ${ }^{53}$ This has been obvious since the colonial era and still remains with some pesantren policies even now. However, for the Pesantren Sidogiri community, this approach is regarded as no more than a manifestation of an attempt to keep good traditions to develop 'kemandirian' teaching (self-reliance) not as an opposition towards the Indonesian government policy. As Ustādh M states:

\footnotetext{
${ }^{52}$ Interview with Kiai M, January 19, 2019.

53 Nurcholis Madjid, Bilik-Bilik Pesantren Sebuah Potret Perjalann (Jakarta: Paramadina, 1997).
} 
"One of the important teaching values in Pesantren Sidogiri is self-reliance; it is based on prophet teachings: 'self-reliance is the foundation to be successful'. Based on this principle, we work hard in order not to depend on others, society and even the Indonesian government. We have a slogan 'we should contribute to this country', therefore we think about what we should give to this country not what we should get from this country" ${ }^{54}$

This is to say, once again, for Pesantren Sidogiri that selfreliance and independence is not opposed to the state but deeply independent in its ability. In terms of financial support and educational programs the Pesantren is independent from outside intervention. Therefore, the idea of social and educational programs from Sidogiri is more directed to the needs of the surrounding pesantren community, rather than to the State programs.

Meanwhile, a different approach is shown at Pesantren Nurul Jadid. According to Kiai $\mathrm{M}$, the financial support from the Indonesian government to the Pesantren Educational system is still considered far beyond necessity. Kiai M states:

"I think, currently, Pesantren Nurul Jadid is already developing toward global competition in education. This phenomenon is something that cannot be avoided. Therefore, we need better facilities as well as competent teachers, particularly in the field of sciences such as mathematics, biology and chemistry. For this reason, we still need and are open to any kind of support such as government financial support as well as the support from competent teachers". ${ }^{5}$

From the phenomenon above, Pesantren Nurul Jadid views the relationship between pesantren and external parties needs some changes, since the challenges of pesantren, regarding the development of knowledge and sciences in the globalization era, are different to the challenges in the past. The openness to any external effort, such as from the Indonesian Government and AusAid; for the pesantren educational reform is seen as an opportunity to transform the pesantren as a 'modern educational institution'.

Based and the above data it is also argued that the Indonesian government regulation, in the era of reform, leads to a significant

\footnotetext{
${ }^{54}$ Interview with Ustādh M, February 19, 2019.

${ }^{55}$ Interview with Kiai M, Karanganyar, March 11, 2019.
} 
contribution to the enhancement of the pesantrens' legal standing as their qualifications are recognized in the Indonesian educational system. This was shown by the establishment of real cooperation between the Indonesian Government (i.e. Department of Religious Affairs) and the pesantren community through providing scholarships, as well as acknowledging pesantren's qualifications. As a result pesantren's students can access further educational opportunities in Indonesian universities, not just limited to Islamic universities but also non-Islamic universities.

Seen from the relationship between pesantren and state in the reform era, it seems that the relationship has changed considerably. Therefore it is argued that the role of pesantren in the globalization era is more complex. Pesantren need to maintain their cultural identity as canters of Islamic teachings, while at the same time adapt their intellectual tradition to engage with a globalizing world.

Seen from the State policy, pesantren, through some programs set by the MORA, seem to have gradually served the national interest within the global marketplace. This can be seen from their effort to build a relationship or partnership between Indonesian universities and foreign foundations. Partnerships with pesantren and Indonesian universities, NGOs and foreign donors concerned with education are regarded simply as strategies to enter the global market. In short, in the reform era, pesantren as social and educational institutions are not marginalized anymore.

\section{Conclusion}

From the description above, it could be argued that globalization increases the complexity and the necessity of learning and teaching processes, particularly in preparing and training santri in dealing with challenges. For the pesantren community, the relations between globalization and certain forms of local cultures have been seen more as complementary rather than contradictory. In this sense, education in the era of globalization will facilitate the young generation of pesantren to a wider spectrum of knowledge. This phenomenon of shifting educational orientation in pesantren is comparable with 
Sadaalah's $\mathrm{s}^{56}$ and Hefner' $\mathrm{s}^{57}$ contention that the Islamic educational system in the contemporary era tends to accept and transform the general education or secular subjects into their educational system. In short, the responses of pesantren on global challenges have been shown through the transformation of its traditional system, namely curriculum development and leadership. In terms of the former, pesantren have now achieved a level where teaching subjects are no longer limited to classical texts, but expanded to secular subjects, which were not common in the past.

This paper concluded that because of the need to develop new educational programs, pesantren does not only depend on charismatic kiai as a single leader with full authority, but also relies on the collective leadership that includes the pesantren shareholders (the kiai family) as well as stakeholders (i.e. santri's parents and alumni). In other words, the management complexity can no longer be placed in the hands of a single leadership model. Consequently, a collective leadership is being widely implemented as the alternative model.

With respect to cultural dimension, this research found that there has been a transformation in the relationship between kiai, the surrounding community and the outside world. Although representing Pesantren Salaf (traditional), the pesantrens' management has endeavored to adapt to modern technology. The pesantren educational programs also provide specialization for santri in the field of $d a^{\prime} w a h$ (communication). The pesantren has its own website and provides electronic messaging services for public relations in regards to religious and social matters, so that the public can access the Pesantren's programs and services. In this sense, there is no need to see the kiai in person, since the kiai also provides special numbers direct to the public. However, not all who need the kiai's advice use ICT (information communication and technology), relatively due to the expensive costs and the limited access of electronic services. Evidence supports, to some extent, Esposito's proposition that a religious leader should accept modern technology in order to spread the Islamic messages to the

\footnotetext{
${ }^{56}$ Sadaalah, Islamic orentation and education, 48-49.

${ }^{57}$ Hefner and Zaman, Schooling Islam, 2-35.
} 
community; as a result Muslim villages do not depend solely on their local religious leaders to interpret religious teachings. ${ }^{58}$

This paper also shows that the contemporary patterns of change in pesantren, where Islamic teachings are no longer the only subject taught to santri, has become a trend. By this, we mean that pesantren, particularly Pesantren Salaf that were traditionally reluctant to adopt changes, are now transforming. Moreover, in the reform era, the Indonesian Government has also integrated pesantren into the national education system. This integration is supported particularly through Law No. 20/2003 on the National Educational System (Undang-Undang Sistem Pendidikan Nasional). The Law effectively identifies Pondok Pesantren as a subsystem of the national educational system. This policy is also continuing through the efforts to develop the Rancangan Undang-Undang Pesantren (RUU or the draft of law for pesantren educational system) in 2019 during Mr. Jokowi President era. Therefore, for futher studies, I argue it is important to explore the Indonesian Islamic educational policy after the RUU Pesantren is signed by Indonesian authority.

\section{References}

Abdullah, Taufiq. "The Pesantren in Historical Perspective." In Islam and Society in Southeast Asia, edited by Taufiq Abdullah and S. Siddique, 80-107. Singapore: Institute of Southeast Asian Studies, 1996.

Appadurai, Arjun. Modernity at Large: Cultural Dimension of Globalization. Minneapolis: University of Minneapolis Press, 1996.

Basyuni, Muhammad Maftuh. Revitalisasi Spirit Pesantren: Kiprah, dan Refleksi. Jakarta: Departemen Agama Republik Indonesia, 2007.

Birch, David. Asia: Cultural Politics in the Global Age. Australia: Allen \& Unwin, 2001.

Carnoy, Martin, and Diana Rhoten. "What Does Globalization Mean for Educational Change? A Comparative Approach."

${ }^{58}$ Esposito, The Islamic Threat. 
Comparative Education Review 46, no. 1, special issue on the meanings of globalization for educational change (2002): 1-9.

Charlene, Tan. "Educative Tradition and Islamic School in Indonesia." Journal of Arabic and Islamic Studies 14 (2014): 4762.

Currie, Jan, and Janise Newson. Universities and Globalisation (Critical Perspectives). London: SAGE Publications, 1998.

Daun, Holger. Educational Restructruring in the Context of Globalization and National Policy. New York: Routledge Falmer, 2002.

Daun, Holger, and Geofrey Walford. Educational Strategies among Muslim in the Context of Globalisation: Some National Case Studies. Netherlands: Brill NV, 2004.

Dhofier, Zamakhsyari. Tradisi Pesantren. Jakarta: LP3ES, 1982.

Duignan, P. Educational Leadership: Key Challenges and Ethical Tension. Cambridge: University Press, 2006.

Esposito, John L. The Islamic Threat: Myth or Reality. New York: Oxford University Press, 1992.

Fuad, Muhammad. "Islam, Modernity and Muhammadiyah's Educational Programme." Journal Intern-Asia Cultural Studies 5, no. 3 (2004): 401-414.

Geertz, Clifford. "The Javanese Kijaji: The Changing Role of a Cultural Broker." Comparative studies in Society and History 2, no. 2 (1960): 228-249.

- - - The Religion of Java. Chicago: University of Chicago Press, 1976.

Giddens, Anthony. Beyond Left and Right: The Future of Radical Politics. Cambridge: Polity Press, 1994.

Haedari, Amin. Transformasi Pesantren. Jakarta: Lekdis \& Media Nusantara, n.d.

Jainuri, Ahmad. "The Reformation of Muslim Education: A Study of the Aligarh and the Muhamadiyah Educational System." Journal IAIN Sunan Ampel 15 (1999): 202-28.

Le Compte, Margarate Diane, and Jean J Schensul. Designing and Conducting Ethnography Research. Walnut Creek: Altamara Press, 1999.

Lukens-Bull, Ronald A. Peaceful Jihad. London: Palgrave Macmillan, 2005. 
- - - "Two Sides of the Same Coin: Modernity and Tradition in Islamic Education Indonesia." Journal Anthropology \& Education Quarterly 32, no. 3 (2001): 350-372.

Madjid, Nurcholis. Bilik-Bilik Pesantren Sebuah Potret Perjalann. Jakarta: Paramadina, 1997.

Muluk, Safrul, Habiburrahim Habiburrahim, Teuku Zulfikar, Janice Orrell, and Mujiburrahman Mujiburrahman. "Developing Generic Skills at an Islamic Higher Education Institution Curriculum in Aceh, Indonesia." Higher Education, Skills and Work-Based Learning 9, no. 3 (January 1, 2019): 445455. Accessed May 8, 2020. https://doi.org/10.1108/HESWBL06-2018-0064.

Robertson, Roland. Globalization: Social Theory and Global Culture. London: Sage, 1992.

Schwandt, Thomas, A. "Three Epistemological Stances for Qualitative Inquiry: Interpretivism, Hermeneutics and Social Constructivism." In The Handbook of Qualitative Research, edited by Norman K. Denzin and Yvonna S. Lincoln, 189-213. 2nd ed. London: SAGE, 2000.

Stephen, Julie. Approach to Globalisation. Melbourne: Victoria University, 2007.

Talbani, Aziz. "Pedagogy, Power, and Discourse: Transformation of Islamic Education." Comporative Education Review 4, no. 1 (1996): 66-82.

Usa, Muslih. Pendidikan Islam di Indonesia antara Cita dan Fakta. Yogyakarta: Tiara Wacana, 1991.

Wiseman, John. Global Nation? Australia and the Politics of Globalisation. Cambridge: Cambridge University Press, 1998.

Zarkasyi, Abdullah Syukri. "Langkah Pengembangan Pesantren." In Religiusitas Iptek, edited by M. Anies. Yogyakarta: Pustaka Pelajar, 1998.

Zia, Rukhsana, ed. Globalization, Modernization and Education in Muslim Countries. London: Sience Publisher, 2006. 